Commissioner for Natal 1936 NPD 94, Moepi v Minister for Bantu Administration and Development 1965 (1) SA 533 (T). On the role of the chief (and headmen) in customary courts, and scope of his power: Makapan v Khope 1923 AD 551, Mokhatle \& Others $v$ Union Government (Minister of Native Affairs) 1926 AD 74, Modisane v Makgotho 1928 TPD 487, Morake v Dubedube 1928 TPD 625, Rex $v$ Kumalo and Others 1952 (1) SA 381 (A), Rex v Ntwana 1961 (3) SA 123 (E), State v Mngadi [1971] 2 All SA 394 (N).

3. South African Law Reform Commission Discussion Paper 82 (Project 90), May 1999, South African Law Reform Commission Report on Traditional Courts and the Judicial Function of Traditional Leaders (Project 90), January 2003 and Draft Submission for Comment: Traditional Courts and the Judicial Function of Chiefs - CALS, CGE and NLC, November 1999.

4. See, for example, 'The Traditional Courts Bill of 2008: documents to broaden the discussion to rural areas'. A publication of the Legal Resources Centre and the Law, Race and Gender Unit, Faculty of Law, University of Cape Town, November 2009 at section 4(3); A Claassens and S Ngubane, Women, land and power: the impact of the Communal Land Rights Act, in A Claassens and B Cousins (eds.), Land, power \& custom: controversies generated by South Africa's Communal Land Rights Act, Cape Town, UCT Press, 2008, 154-183; A Claassens and S Mnisi, Rural women redefining land rights in the context of living customary law, South African Journal on Human Rights 25 (2009), 491; S Mnisi, The interface between living customary law(s) of succession and South African state law, Unpublished DPhil thesis, University of Oxford, 2010.

5. Mönnig, The Pedi, 309; Dutton, The Basuto of Basutoland, 59-60.

6. Except in cultural systems where they had their own systems of courts (as in Pedi culture) or, as in the case of the Swazi, where the Queen would hear appeals in the court immediately beneath that of the King who was her son or where, as in the Lovhedu, a woman was the figurehead in the court, as chief. See Mönnig, The Pedi; Kuper, An African aristocracy.

7. Dutton, The Basuto of Basutoland, 59-60. Even in the case of the more presiding officer-like role of the Tswana judge, according to Comaroff and Roberts, Rules and Processes, $80-83,180$, as with legislative pronouncements, the legitimacy and efficacy of the chief's decisions or rules that are developed in cases depend on (i) their reflection of public opinion, (ii) their being delivered by an authority considered legitimate and (iii) their utility to individuals in the circumstances in which the rule might later be raised. The first criterion introduces the dimension of community participation to the process because, as Comaroff and Roberts observe, the chief must usually consult widely. It is also important to observe that the second of these conditions is often lacking where the apartheid government imposed the existing traditional authorities and institutions. Also see Cook, Social Organisation and ceremonial institutions of the Bomvana, 146 and Reader, Zulu tribe in transition, 259-60.
8. Ibid. Also see Mnisi, The interface between living customary law(s) of succession and South African state law.

9. See note 7. With regard to the Xhosa, HammondTooke, Command or Consensus, 68, $74 \mathrm{fn} 13$ notes that decisions are made by the 'community-in-council'. Indeed, he writes (at 67) that '" [a] chief who dared to go against the wishes of his people ran the risk of losing their support, and perhaps his chieftainship." ... Consensus was all important.' Also see the following cases for the claims made to them, more than for the findings of the courts: in Morake v Dubedube 1928 TPD 625 at 630 the court describes the chief as 'sitting in that capacity, advised by his counselors' and wrongly rejects the contention that the chief (and his council) does not possess in him the customary law; Rex $v$ Kumalo and Others 1952 (1) SA 381 (A) speaks of the chief and members of his council as deciding upon the proper punishment for a man for contempt of court; Rex $v$ Ntwana 1961 (3) SA 123 (E) also notes the council and headmen's role in the traditional dispute resolution process; State v Mngadi [1971] 2 All SA 394 (N) similarly notes the headmen's involvement in the processes of dispute resolution.

10. Mönnig, The Pedi, 308; Wilson et al, Keiskammahoek rural survey vol 3, Schapera, Tribal Innovators, 92.

11. Kuper, An African aristocracy, 65.

12. Hammond-Tooke, Command or Consensus, 64.

13. See the Black Administration Act sections 12 and 20, which regulated traditional courts under the respective titles, 'Settlement of civil disputes by native chiefs' and 'Powers of chiefs to try certain offences'. See the amended titles, pursuant to the Native Administration Amendment Act 1929 (9 of 1929) and the Native Administration Amendment Act 1943 (21 of 1943) respectively, 'Settlement of civil disputes by Black chiefs, headmen and chiefs' deputies' and 'Powers of chiefs, headmen and chiefs' deputies to try certain offences'.

14. M Chanock, The making of South African legal culture, 1902-1936: fear, favour and prejudice, Cambridge, Cambridge University Press, 2001, 262, 267; A Claassens, Women, customary law and discrimination: the impact of the Communal Land Rights Act, Acta Juridica 42 (2005), 50; M Mamdani, Citizen and subject: contemporary Africa and the legacy of late colonialism, Princeton, Princeton University Press, 1996, 81; T Nhlapo, The African customary law of marriage and the rights conundrum, in M Mamdani (ed), Beyond rights-talk and culture-talk: comparative essays on the politics of rights and culture. Cape Town, David Philip Publishers, 2000, 136-48 at 161-3; R Roberts, Litigants and households: African disputes and colonial courts in the French Soudan, 1895-1912, Portsmouth, NH, Heinemann, 2005, 18-20.

15. See Makapan $v$ Khope, 555 where the court correctly recognises the headman's court on grounds that it was 'recognized by members of the tribe as having authority to hear and decide disputes'.

16. Wilson et al, Keiskammahoek rural survey vol 3.

17. Kuper, An African aristocracy, 65.

18. Hammond-Tooke, Command or Consensus, 67, 68.

19. Reader, Zulu tribe in transition, 259-60. His fieldwork having been done pre-1951, Reader observes that 'in no 
aspect of Makhanya life has the South African Administration intervened more decisively than in the judicial sphere'. He says that the legal system there is a complex of European and tribal judicial institutions which have gradually come together over a period of more than 100 years.

20. Hammond-Tooke, Command or Consensus, 78.

21. Roberts, Litigants and households. Some of the cases cited above, note 2, are examples of these appeals to the state to defend them against abuse of power by traditional authorities. These include Hermannsburg Mission Society $v$ The Commissioner for Native Affairs and Darius Mogalie 1906 TS 135 and Rathibe v Reid 1927 AD 74 on whether the chief must consult with the community or act in accordance with the advice of the council, respectively, in his execution of his 'trustreeship' role vis-à-vis the land of the tribe; Mandhlakayise Ngcobo $v$ Chief Native Commissioner for Natal 1936 NPD 94, where the court addresses the tribe's dissatisfaction with its leader, one component of which is the chief's appointment of a principal induna without consulting the tribe; Rex $v$ Magano and Madumo, 1924 TPD 129 on a similar matter of the chief's need to consult the community; Moepi v Minister for Bantu Administration and Development 1965 (1) SA 533 (T), in which a tribal community, led by the chief's councilmen, brought a chief before the Bantu Commissioner for his failure to consult the headmen on matters which required their approval; Mathibe $v$ Tsoke 1925 AD 105 at 116 concerning the opportunity for the community to object on whether a new levy should be imposed on them.

22. Sections 1 and 4 of the TCB.

23. See Makapan $v$ Khope, 555 where the court finds that, in terms of section 4 of Law 4 of 1885, 'a chief appointed by the government [is constituted] to be a court of justice'.

24. Claasens and Ngubane, Women, land and power, 1735; Claassens and Mnisi, Rural women redefining land rights in the context of living customary law; E Curren and E Bonthuys, Customary law and domestic violence in rural South African communities, South African Journal on Human Rights 21 (2005), 607, 633; T Higgins, J Fenrich and Z Tanzer, Gender equality and customary marriage: bargaining in the shadow of post-apartheid legal pluralism 30(6) (2007), 1653, 1700-01; B Oomen, Chiefs in South Africa: Law, Power and Culture in the Post-Apartheid Era, James Currey Ltd, 2005, 140.

25. Again, see Hammond-Tooke, Command or Consensus, 64 , where he observes that, although in theory appeals from lower courts could go to chief's courts in the Transkei, 'it seems this was rare in practice.' He also quotes a regent named Isaac Matiwane as saying that: Subjects of the isiduna were allowed to take their cases on appeal to the chief's court if they were not satisfied with the isiduna's verdict. But such cases were very rare. In fact this was not encouraged.

26. Ibid. Mönnig, The Pedi, 313 also reflects that few people took cases to the Native Commissioner in terms of the Black Administration Act of their own accord, and only chiefs appointed by the central government actually referred cases to them.

27. Section 30 of the Constitution says 'everyone has the right to ... participate in the cultural life of their choice'. (Emphasis added)

28. Section 18 of the Constitution permits 'everyone ... the right to freedom of association'.

29. See PMG report, http://www.pmg.org.za/report/ 20090901-department-justice-constitutionaldevelopment-traditional-courts-bill (accessed November 2010).

30. See Barkhuizen v Napier 2007 (5) SA 323 (CC) at paras 31-35; Giddey NO v JC Barnard and Partners 2007 (5) SA 525 (CC) at para 15; Engelbrecht v Road Accident Fund and Another 2007 (6) SA 96 (CC) at paras 30 and 40 .

31. Ibid.

32. This argument is based on the fact that customary courts do not purport to be independent and impartial in the way that state courts are. In fact, it is sometimes the very fact that they are distinct in this way that attracts the people who choose to use them. (See Mnisi, The interface between living customary law(s) of succession and South African state law, 282-83) However, it is sometimes also the extent of this fact that is responsible for complaints by community members who express the concern that this prevents them from obtaining the objective justice that they would wish. (See Mnisi, The interface between living customary law(s) of succession and South African state law, 222 and 'The Traditional Courts Bill of 2008: documents to broaden the discussion to rural areas').

33. See observations made, in this regard, by K Von Benda-Beckmann, Forum shopping and shopping forums: Dispute processing in a Minangkabau village in West Sumatra, Journal of Legal Pluralism 19 (1981), 117-160, 137-38.

34. With choice, the question arises as to who gets to make it: the plaintiff or defendant. Legislation should possibly provide that, in civil cases, the plaintiff makes the choice by where they initiate proceedings (reserving room and a mechanism for the defendant to object), whilst in criminal cases, the accused should be permitted to make the choice, and move their case after its institution, if necessary.

35. A further justification for people's being able to choose to use the Magistrate's Court as against the customary court is that this would do away with the difficulty created by the TCB, for women especially, in requiring them to challenge the chief as presiding officer directly if they feel that his judgment is unfair. People can, instead, just avoid the chief entirely, which subtly says that they think him and his court incompetent/dysfunctional or biased/malicious, but this means does not require direct confrontation between people of unequal power, influence and means.

36. Section 35(3)(f) gives people the right to legal representation where accused of an offence, and sections 7, 8 and 36 all make the Bill of Rights central to our democracy, subject all laws to it and make it only limitable for constitutionally-compelling reasons. Notably, section 35(3)(f) is a non-derogable right even in a state of emergency.

37. I would not interpret this to exclude the possibility of customary courts hearing and deciding matters pertaining to the transactional elements surrounding 
marriage, e.g. a woman and her family suing the husband's family for outstanding lobolo.

38. I would not interpret this to exclude the possibility of customary courts hearing and deciding matters relating to the cultural aspects of succession, e.g. a woman's having been 'illegally' (in terms of living customary law) made to wear mourning clothes while her husband's family had not officially taken her through the marriage process by virtue of their owing her and her family lobolo, and the monetary/livestock compensation to the woman and her family that might follow such an infraction.

39. This list reflects a comprehensive list combining section 3.4 of the CALS, CGE and NLC 1999 report and clause 8 (1) of the SALRC draft Bill.

40. Wilson et al, Keiskammahoek rural survey vol 3.

41. According to section 10(2)(i) of the TCB: 'benefits that accrue in terms of customary law and custom' may be taken away from the person as a sanction.

42. According to Statistics South Africa, Income and Expenditure Survey, 2008, 156, in 2005/06, the average annual income of rural households was R30 859 as opposed to R98 011 in urban areas - less than a third of the urban average. Of this, salaried income formed an average of R14 250 in rural households relative to the R66 310 of urban households.

43. Because customary courts are typically nonprofessional institutions, their financial needs would be different from those of state courts. For instance, government should ideally provide a meal at the end to those who have participated in a day's court proceedings, as this is one of the costs toward which people's fines are often attributed. In some areas, government already provides modest stipends to headmen, councillors and secretaries, as the people who administratively staff the courts - but only at the chief's court level. (This is in terms of section 5 of the Public Office Bearers Act 1998 (Act 20 of 1998) as amended by section 29 of the Traditional Leadership and Governance Framework Act 2003 (Act 41 of 2003), and section 26 of the Traditional Leadership and Governance Amendment Act (Act 23 of 2009)). As a consequence, many other servants of these courts are often left out e.g. the 'traditional police' (somewhat comparable to the 'sheriff of the court') who, in some instances, does the bulk of the running around for summoning people to the court and enforcing judgments, as well as sometimes even hearing cases and intervening in physical/violent disputes.

44. Examples of these are given in the Substantive Report on National Community Workshop on Traditional Courts Bill, 11-12 November 2009.

45. While the adoption of such accountability mechanisms as those proposed here might appear entirely improbable, the establishment of the Department of Traditional Affairs makes them a little less so. Its mandate (according to its concept document for the project titled 'Assessment of the State of Governance within the Institution of Traditional Affairs') is partly to 'assist the institution of traditional ... leadership to transform themselves to be strategic partners with Government in the development of their communities but also to coordinate the traditional affairs activities of the Department and those of other departments at national, provincial and local government levels. This is meant to ensure that their needs in terms of development, service delivery, governance, access to indigenous knowledge systems, traditional courts and indigenous law, traditional healing and medicine, etc are adequately met.' (point 2.10 at 4 ; emphasis added). The document envisages that this department will play an oversight role described as including, as the second one of its four focus areas: 'To develop, review, monitor and implement legislation and policies relevant to traditional leadership nationally and to coordinate and monitor the review and implementation of legislation and policies relevant to traditional affairs by national and provincial government departments' (point 2.11 at 4; emphasis added). This is indeed an ambitious project. But, were the Traditional Courts Bill to be replaced by progressive legislation, it at least seems feasible that this legislation could exploit the expressed will of government to provide some degree of oversight, and thus secure the kind of oversight necessary to see the implementation of the replacement legislation.

46. Tongoane and Others $v$ National Minister for Agriculture and Land Affairs and Others at para 106; also see Doctors for Life International $v$ Speaker of the National Assembly and Others 2006 (6) SA 416 (CC) at para 211. 


\section{On the record...}

\section{Interview with the Deputy Minister of Cooperative Governance and Traditional Affairs, Yunus Carrim}

Mazibuko K. Jara, ${ }^{*}$ interviews Yunus Carrim, ${ }^{* *}$ Deputy Minister of Cooperative Governance and Traditional Affairs, about the Traditional Courts Bill and its implications.

Mazibuko Jara (MJ): The boundaries to be used for the jurisdiction of the traditional courts envisaged in the Traditional Courts Bill (TCB) are the same as those imposed by the apartheid-era Black Authorities Act of 1951 (BAA); that is because the TCB's default jurisdictional boundaries of traditional courts are the same as those of the BAA. In your view, do the TCB and other laws, such as the Communal Land Rights Act of 2004 (CLARA) and the Traditional Leadership and Governance Framework Act of 2003 (TLGFA), entrench these BAA tribal boundaries and structures?

Yunus Carrim (YC): I can speak about the TLGFA because I was chair of the Portfolio Committee on Local Government when the Bill was processed. When it comes to the TCB, the Justice and Constitutional Development portfolio committee, which I chaired at the time, had little time to deal with the Bill. It was tabled just before the 2009 national elections. But there was too much conflict over the Bill. We proposed to the incoming committee that they should see to it that public hearings were started again, because many civil society stakeholders claimed that the Department of Justice's public hearings were biased. It was said that many of the hearings were held in tribal courts, which did not provide a conducive atmosphere for citizens with different

\footnotetext{
* Senior Researcher, Law, Race and Gender Research Unit, University of Cape Town.

** Yunus Carrim was chair of the Parliamentary Portfolio Committee on Justice and Constitutional Development when the TCB was introduced to parliament.
}

views. But it was impossible to complete the TCB process, given the imminent end of our five-year term in parliament. That matter is now on the agenda of the Justice Committee chaired by Llewellyn Landers.

When I chaired the Local Government Committee we did not use the BAA at all as a basis for processing the TLGFA. We looked at what we understood to be happening on the ground. The context of nation-building, and the need to bring traditional leaders into the post1994 framework were also important considerations. As a portfolio committee, we jettisoned the BAA. We recognised that the traditional leadership institutions will not disappear overnight. We also recognised that the post-1994 situation made traditional leaders feel that there was now a new government that could understand them. Many felt a sense of pride and dignity, which for some included the impulse to restore traditional institutions to what they saw as their rightful place. Some even wanted the restoration almost to return to the pre-colonial era. We had to respond to them. If we had traditional institutions outside of the legislative process, it could have led to problematic and antidemocratic practices in some parts of the country.

One must not look at the TLGFA without looking at the Nhlapho Commission (the Commission on Traditional Leadership Disputes set up by the TLGFA). Many came to the ANC and said, 'we are genuine traditional leaders who were displaced by apartheid because we were not yes-men.' The ANC had to say that you cannot be a traditional 
Former homelands map, 1986

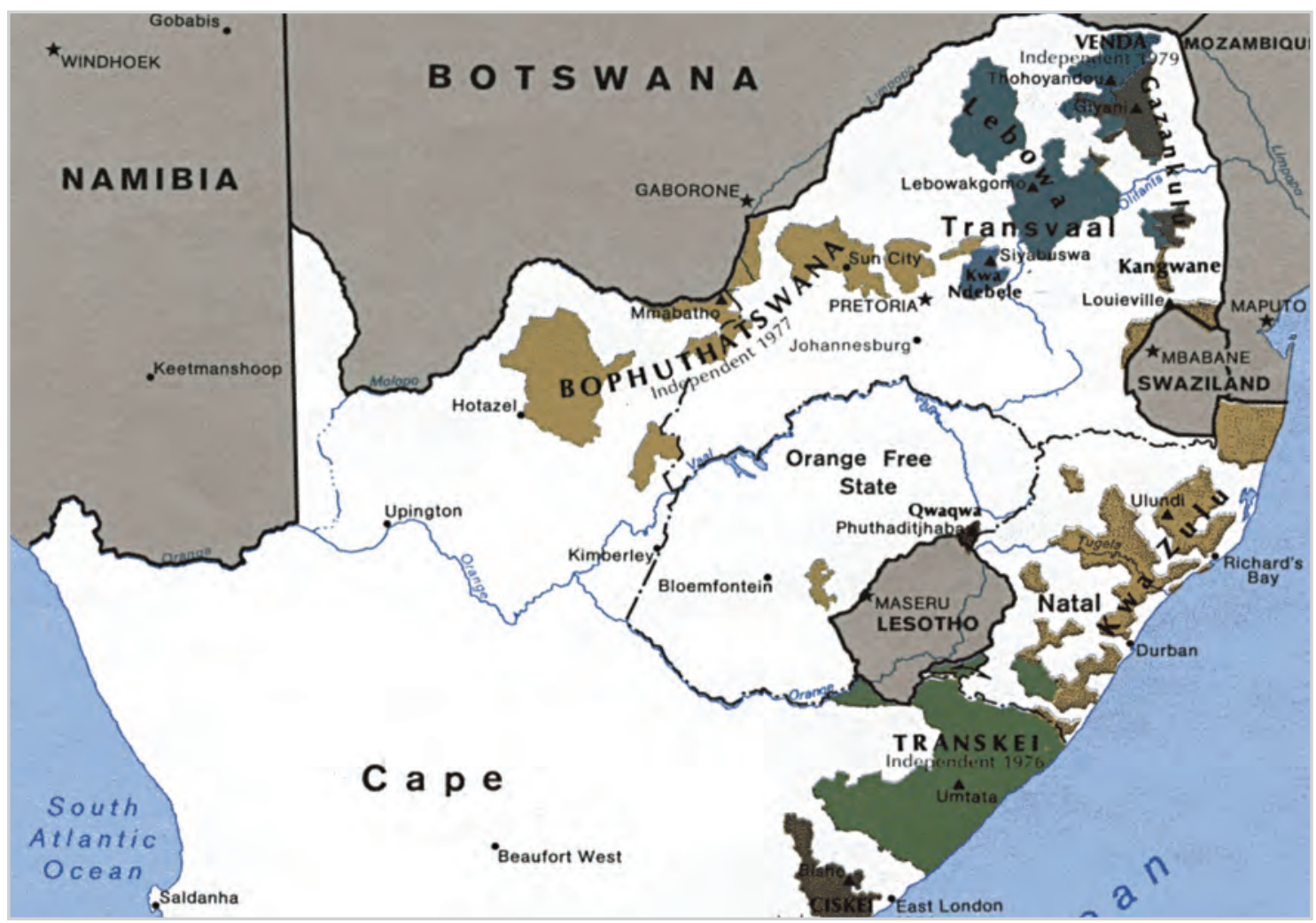

Traditional Council map, 2010

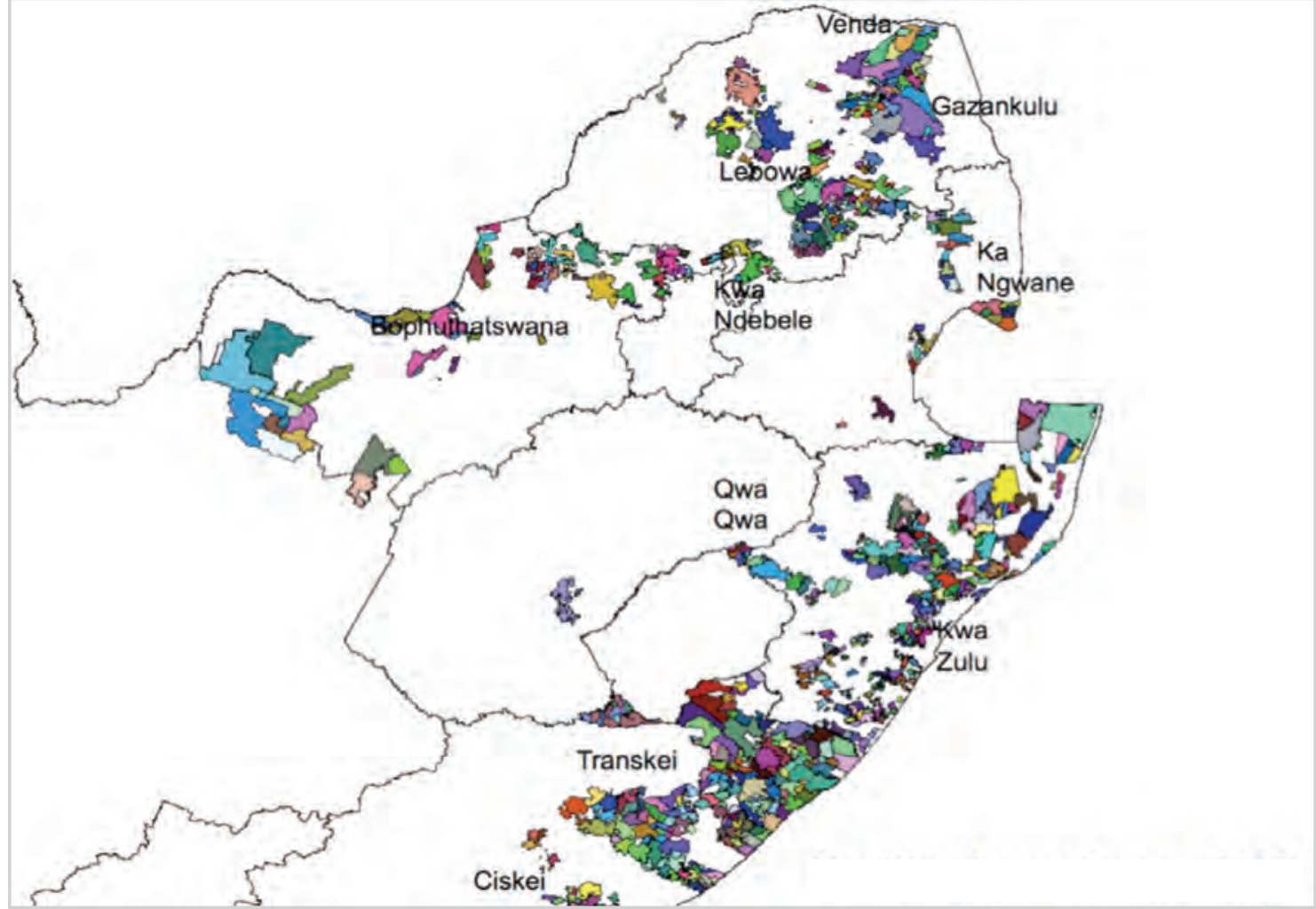


leader if the apartheid regime appointed you - if you were one by legitimate custom, so be it; but if imposed we cannot recognise you as one. So, the post-1994 era allowed those who are genuine traditional leaders to remain. The BAA did not allow for that, as it had a particular notion of advancing Bantustans, clan and ethnic divisions, and other elements of apartheid rule. The TLGFA now enables traditional leaders to contribute to social cohesion and the development of rural people. I disagree with the view that parliament relied on the BAA in passing the TLGFA.

I cannot recall the specific discussions on tribal boundaries when the TLGFA was passed. However, government can consider a review of traditional boundaries as we are presently preparing an overhaul of legislation relevant to the roles of traditional leaders.

One has to understand that Act (the TLGFA) in the context of the unfolding political process of change we were in at the time. We did not have a revolution in the Marxist sense but a negotiated transfer of power, a 'democratic breakthrough', as the SACP says. We are an emerging democracy. We cannot overnight dismantle all the structures of the order that we overthrew. What we settled for in 1994 meant that we compromised on certain things. For example, we had to ensure a balance between socio-economic rights and the rights of the market to operate. My understanding is that, whatever our views on traditional leadership, the TLGFA was reasonable in the circumstances. It recognises that democracy must prevail, but a democracy shaped in the context of specific structural, cultural and historical circumstances. The TLGFA is a reasonably balanced piece of legislation, taking into account the conditions of the time. It does not entrench traditional leadership institutions in a way that undermines democracy. This challenge of modernity and tradition persists in many forms across the world - for example, even progressive trade unionists in Britain are taken up by the upcoming royal wedding.

Before the TLGFA, I think that what we did is communicate the ANC's positions on traditional institutions through the Municipal Structures Act (MSA). That meant that at local level it is the elected councillors that have overall responsibility and decision-making power on development. But councillors must work with traditional leaders.

The TLGFA must be located in terms of the MSA.

We also recognised that there are large numbers of rural poor who identify with traditional leaders. And the state alone cannot deliver services. In the same way that we need civil society support, traditional leaders can also play a developmental role. Some of them played this role. Through the TLGFA we gave them a more developmental role in an enabling framework that allows each province to work according to local dynamics to shape their own legislation. The TLGFA was not prescriptive legislation. Clearly, what we provided for was a developmental role for traditional leaders, while making it clear that ultimately it is elected public representatives who must take responsibility for service delivery and development. The two need to work together. In the TLGFA we also provided for participation by women in a way that breaks with some discriminatory practices in most of these traditional communities.

The TLGFA was also seen as an interim model until conditions change for a more democratic model. It was not seen as a final answer. Further changes would be on the basis of what is happening on the ground: struggles, contestations and so on. The law reflects the state of those struggles, the conditions on the ground. But of course, the law also has to open space and assist in advancing those struggles.

We were also concerned to enhance the many good and positive aspects of traditional leaders. The ANC itself has a good history with traditional leaders. People like Inkosi Albert Luthuli and Inkosi Zibuse Mlaba in Camperdown are positive examples. It is crude to argue that traditional leaders are inevitably holding back progress. As a deputy minister in this portfolio, I meet often with amakhosi. I am often surprised by the huge potential they have to contribute to development. 
Ultimately, it is not just what the law says but also how the law is executed in practice. It is what the MECs and departments understand the law to be. One is aware of the way in which the law can entrench and embed these institutions but these are matters for struggle and local dynamics. As we industrialise and modernise, the chances are that we will be in a better position to accommodate traditional leadership in ways that are more consistent with a progressive democracy. But it is not given that modernisation will do away with traditional systems, views and institutions. Consider, for example, how ethnic and religious differences can emerge in the most modern industrialised societies. What do you say of Muslims born and bred in the UK who turn to Islamic fundamentalism? There are other examples, of course.

Of course we could have done better on the TLGFA. There may be counter-productive features in the TLGFA, including the position of women, the extent of democracy, and urban-rural divisions. But there is now enough space to experiment and improve.

I did not deal with CLARA at all. I was taken aback by CLARA as it surfaced. Some of the civil society people were upset with us as a portfolio committee. They felt that we were accommodating a broad range of views on the TLGFA, but CLARA undermined all of that. I did not know that CLARA was coming out in the way it did. For the TLGFA we allowed for public hearings. We continued to engage with civil society and the traditional leaders till the day we voted on the Bill. We even gave the last version of the Bill to stakeholders for comment, provided they did not raise the same issues on which progress had been made. I did a lot of the negotiating myself. As a result, we struck various balances. The stakeholders and technical experts on all sides were reasonably happy with the way we dealt with the TLGFA. I know certainly that people were not always happy with the final version, but they were reasonably satisfied, even if not altogether happy. When CLARA came up, some of the civil society organisations felt that we were giving them a good TLGFA, yet CLARA was a problematic law. We were like the 'good guys', while the committee dealing with CLARA were the 'bad guys' - but we were both part of the same 'plan', as it were. But even some senior government and ANC representatives did not seem to know exactly what the provisions of CLARA were. The ANC can at times be erratic, haphazard, vague. But there was not the conspiracy some civil society stakeholders claim.

MJ: The TCB does not enable people to opt out of using traditional courts, as was recommended by the Law Commission. Instead it makes it a criminal offence for anyone living within the jurisdiction of a traditional court to fail to appear once summoned by the senior traditional leader as presiding officer. ${ }^{1}$ Can you explain whether this is consistent with the Constitution? What will the impact of this be on public respect, trust and confidence in traditional leaders, given that your department sees them as partners in the system of cooperative governance, which includes participation by ordinary people? What is your assessment of the scope of the TLGFA provisions for people to opt out from traditional community status? Can a portion of a 'traditional community' have the right to opt out? How?

YC: People have a right to opt out. That's what our committee felt. If a person does not want to abide by the norms and values of the traditional authority, surely that person has a right to opt out? The legal advice we got was that it would be unconstitutional not to give people from traditional authority areas that right. This is a matter that will have to be addressed by the current Justice Committee as it processes the Bill.

MJ: The concept document for the new Department of Traditional Affairs makes mention of oversight and accountability mechanisms for traditional courts. This seems to suggest that the department would play a role in ensuring the accountability it is seeking. How does the department seek to achieve these goals, and is it involving the Department of Justice in this? Is there a correlating budget that would accompany these tasks? How conducive is the environment for accountability by traditional leaders given the 
combined impact of the TCB and the TLGFA to fuse judicial, administrative and governance functions in one structure/person/institution?

YC: Legislation dealing with these issues comes from three different departments: the Department of Cooperative Governance and Traditional Affairs, the Department of Rural Development and Land Reform and the Department of Justice and Constitutional Development. There obviously needs to be synergy between us. This needs to be addressed. We can fine-tune this in the overhaul of legislation I have mentioned. The overall principle should be the need for the separation of powers to ensure accountability - how we do it is something we need to apply our minds to. If the TLGFA collapses different roles, we must look at it and arrive at consensus on what to do. I agree with the issues about accountability of traditional leaders. This is the position of the department.

\section{MJ: Critiques of the TCB, TLGFA and CLARA} have argued that these laws fail to recognise the diversity and the multi-layered nature of traditional justice, customary law and customary governance systems. What is your view? Do these laws not concentrate power, responsibilities and role in traditional courts and councils that are both dominated by a senior traditional leader? What about the fact that the TLGFA dissolves community authorities?

YC: The TLGFA was an enabling framework act. The intention was to allow for diversity. It is possible that we did not make adequate provisions to recognise this diversity. If that is the case, there is an opportunity to address it now. Right now, government is overhauling relevant legislation: in particular the TLGFA and the National House of Traditional Leadership Act (NHTLA). We hope this will be tabled in parliament in the second half of this year. The department is finalising a discussion document on this. We can consider submissions on community authorities and other customary structures.

MJ: Can the TLGFA (section 20 in particular) be interpreted to mean that the role of traditional leaders includes governance? Do traditional institutions not constitute a fourth tier of government? What do you make of the Constitutional Court's certification judgment, which specifically rejected the assertion that the roles of traditional leaders included governmental powers?

YC: The Framework Act does not create a fourth tier of government. Traditional leaders are part of our constitutional democracy. What we sought to do was to avoid a situation where traditional leaders would be seen as a fourth tier. The TLGFA provides for a complementary relationship between traditional leaders and elected public representatives. It gives some sort of structure and cohesion to the relationship between traditional leaders and democracy. But it's possible that the way the roles and responsibilities of traditional leaders are applied in practice may, in some cases, serve to create the impression of a fourth tier of government. The Act did not intend this. This is not consistent with the Constitution or values of government or the ANC. If this is the case it needs to be attended to.

MJ: What are the implications of the pending changes to municipal laws regarding the roles of traditional leaders in municipal councils? And the implications for the democratic transformation of local government? Does this not give traditional leaders governmental powers?

YC: What we are talking about are roles, but not an established legislative provision for the same power as public representatives. The views of the current government allow space for a direct developmental role for traditional leaders. But this must be within the framework of democracy. We are not talking about the same powers as public representatives for traditional leaders at this stage, but a greater developmental role. However, an increase in traditional leader powers is a possible outcome, given the review and overhaul of the legislation, and we're not sure what sort of consensus will emerge or what Parliament will decide. The intention is to merge the NHTLA with TLGFA into one overall piece of legislation. Whether they will get more powers is difficult to 
say. There is government recognition that traditional leaders can play more of a role - as all actors outside the state can play more of a role.

MJ: The TLGFA was justified by reference to the reform component of tribal authorities through the allocation of a third of seats in new traditional councils to women, and for the election of $40 \%$ of its members. The TLGFA stated that such elections would be held by the end of 2004. Yet it is common cause that the elections were botched in KwaZulu-Natal, North West, the Eastern Cape and Mpumalanga, and still have not taken place in Limpopo. Why is it that eight years after the TLGFA was passed in 2003 the election of $40 \%$ of the members of traditional councils has not yet taken place in provinces such as Limpopo?

YC: If there were problems, obviously they need to be addressed. Limpopo, I know, posed certain specific problems and the department has been seeking to address them. You must remember that we have to work with the provincial departments on this. Now that we have a separate, dedicated Department of Traditional Affairs within our Ministry, we will be better able to deal with the problems. Some of the problems are understandable, given the complexities of the issues, but others should not have occurred. We have to do more to address them, I agree. The review of the TLGFA and the NHTLA can also address the practical problems in the implementation of the TLGFA.

MJ: What is your message to those rural dwellers concerned about the TLGFA, and the TCB and its impact on rights?

YC: People must take part in the process that will unfold in the next few months. The department will be consulting widely. Parliament will also have public hearings. People are more than welcome to make submissions. We are keen that they do, and we will look at all submissions. We would like to hear more from these organisations. There is an open door to engage with us and, I'm sure, Parliament too.

There is scope for reconciling traditional leaders and a progressive democracy. Given the gigantic challenges around jobs, service delivery, development, HIV/AIDS, the environment and economic growth, and the desperation for progress, I think that we need everybody on board. We need to find a way for traditional leaders to play a role as part and parcel of a progressive democracy. It can be done. Some blindly reject the TLGFA because they do not trust the ANC and government. They do not look fairly at the substance of the TLGFA and the challenges it seeks to address. I think they just don't trust us. If we were trusted more, people might be more willing to see the TLGFA in a more positive light. We must take our measure of responsibility for the lack of trust in us among sections of civil society. If we look at the TLGFA on its own merits and demerits, there will be faults with it, no doubt. But some of those things can be addressed in the process. On some of them we can never agree. From the vantage point of civil society, what they say makes sense. From the vantage point of traditional leaders, the same applies. From government's position, we seek to find consensus on the complementary roles of traditional leaders and elected public representatives as part of a progressive democracy. We cannot exclude traditional leaders. They are part of us. We need to draw them in. We do not need to isolate them. They can play a valuable role in our democracy. There is scope.

\section{NOTE}

1. Section $20 \mathrm{c}$ of the TCB states that any person whohaving received a notice to attend court proceedings, without sufficient cause fails to attend at the time and place specified in the notice, or fails to remain in attendance until the conclusion of the proceedings in question or until excused from further attendance by the presiding officer, is guilty of an offence and liable on conviction to a fine. 


\section{$\mathrm{BAA}=>\mathrm{TLGFA}=>\mathrm{CLRA} \& \mathrm{TCB}$}

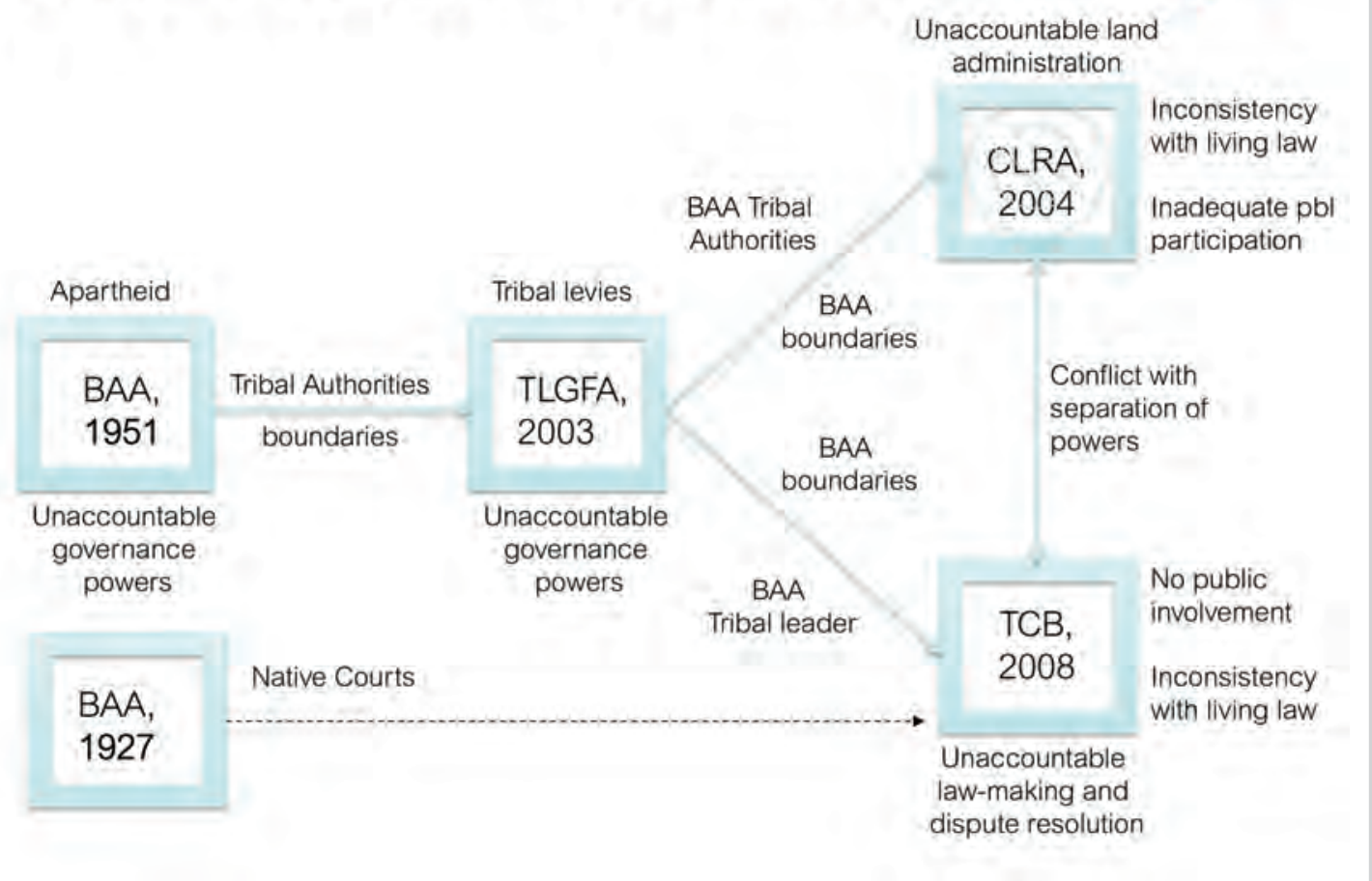

Source: Law, Race and Gender Research Unit, Faculty of Law, University of Cape Town. 